\title{
Environmental factors related to entry into and ascent of fish in the experimental ladder located close to Itaipu Dam
}

\author{
Domingo Rodrigues Fernandez*, Angelo Antonio Agostinho**, \\ Luis Maurício Bini*** and Luiz Carlos Gomes**
}

We evaluated the seasonality of the ascent of fish in an experimental ladder located close to Itaipu Dam, and its relationships to reproduction, temperature, river level and discharge. Samplings of fish and measurements of abiotic factors were performed from February, 1995 through January, 1997, in two resting pools of the ladder. Pool A was located $10 \mathrm{~m}$ above the mean level of the Paraná River; Pool B was located at the upper end of the ladder, at a height of $27 \mathrm{~m}$. Autoregressive models were used to remove the temporal dependence between observations. Residuals of the models were used to relate, using Pearson's correlation coefficient, the densities of fish to the environmental variables. Clear patterns of seasonality were observed for temperature. River level, turbine discharge and spillway discharge, although they showed no clear seasonal dynamics, were timedependent, because the autocorrelation coefficients for different $k$ values were significant. In the samples of larger-sized fish, 23 species were recorded during the two years of study. Most of the individuals were in a non reproductive state, and about $90 \%$ of the individuals belonged to only six species. The temporal variability in total abundance, considering all species, indicated a pattern of seasonal variation; high abundances occurred from October through February (75\%) and in Pool A $(61 \%$ of the 1343 individuals sampled). Low abundances were recorded during winter, with the correlogram of total density confirming this tendency. In the samples of smaller-sized species, six species were recorded, with all six present in both pools, but more frequent in the first pool (64\%). Bryconamericus stramineus comprised $99 \%$ of the total numbers of smaller fish in the samples. The total abundance of small species showed different temporal patterns of seasonal variation in the two years of study.

O presente estudo avalia a sazonalidade da ascensão de peixes na escada experimental localizada junto à barragem da hidrelétrica de Itaipu e as relações com a reprodução, temperatura, nível do rio e suas vazões. As amostragens de peixes e de fatores abióticos foram obtidas de fevereiro de 1995 a janeiro de 1997, em dois tanques de descanso, aqui denominados Caixas, sendo o primeiro, Caixa A, localizado na altura de $10 \mathrm{~m}$ da cota média do rio Paraná, e o segundo, Caixa B, ao final da escada, a $27 \mathrm{~m}$ de altura. Modelos autoregressivos foram empregados com o objetivo de remover a dependência temporal entre as observações. Posteriormente, os resíduos dos modelos foram utilizados para relacionar, através do coeficiente de correlação de Pearson, as densidades de peixes com as variáveis ambientais. Padrões claros de sazonalidade foram observados para a variável temperatura. As variáveis cota, vazão turbinada e vazão vertida, embora não tenham apresentado dinâmicas sazonais claras, foram temporalmente dependentes, tendo em vista que os coeficientes de autocorrelação, para diferentes $k$, foram significativos. Na amostragem de peixes de maior porte foram registradas 23 espécies ao longo dos dois anos de estudo, sendo que a maior parte dos indivíduos não se encontrava em reprodução e cerca de $90 \%$ dos indivíduos amostrados pertenciam a apenas seis espécies. A variabilidade temporal da abundância total, considerando o conjunto das espécies, indicou um padrão de variação sazonal, permitindo evidenciar que os maiores valores de abundância foram observados sistematicamente nos meses de outubro a fevereiro ( $75 \%$ ) e na caixa $\mathrm{A}$ ( $61 \%$ dos 1343 indivíduos amostrados). Os menores valores foram registrados nos meses de inverno. O correlograma da densidade total confirma essa tendência. Nas amostragens destinadas às espécies de pequeno porte, foram registradas seis espécies, todas presentes em ambas as caixas, sendo mais freqüentes na primeira (64\%). Entre essas espécies, Bryconamericus stramineus contribuiu com $99 \%$ do total amostrado. A variabilidade temporal da abundância total das espécies de pequeno porte indicou um padrão distinto de variação sazonal entre dois períodos anuais analisados.

Key words: Fish ladder, Fish migration, Environmental factors, Paraná River.

\footnotetext{
*Itaipu Binacional, Departamento de Meio Ambiente, Av. Tancredo Neves 6731, 85856-970 Foz do Iguaçu, PR, Brazil.

**Universidade Estadual de Maringá, Núcleo de Pesquisas em Limnologia, Ictiologia e Aqüicultura - Nupelia, Av. Colombo, 5790, 87020-900 Maringá, Paraná, Brazil. *** Universidade Federal de Goiás, ICB, Departamento de Biologia Geral, 74001-970 Goiânia, Goiás, Brazil.
} 


\section{Introduction}

Dams and their impoundments block or delay the movement of fish to the upper parts of river basins. The negative impacts of these blockages on reproduction and recruitment are proportional to the degree that species need to move to different parts of their ranges, and to the integrity of critical areas in the remaining non-dammed stretches of rivers (Lucas \& Baras, 2001; Agostinho et al., 2002). To solve these problems, the construction of fish ladders to allow fish access to their spawning grounds has been suggested. However, most of the dozens of fish ladders constructed in Brazil up to now appear to be inefficient (Agostinho et al., 2002; Fernandez et al., 2004). Within the energy and academic sectors, lack of consistent information is considered the primary reason for their poor performance (Britski, 1994; Agostinho \& Gomes, 2005).

Water discharge within a fish ladder and down the river itself is a fundamental element in attracting fish. The amount of discharge must allow fish to maintain position or advance without undue stress, and to facilitate ascent, resting areas should be available (Larinier, 2002a). To encourage entry, the water velocity in the ladder must be higher than in the river, but enough to allow fish to move against the current (Clay, 1995; Larinier, 2002b).

Motivations that lead fish to migrate upstream over long distances in the Paraná River, which could explain why they ascend the ladder, are poorly understood. Nevertheless, it is known that fish have reproductive and feeding motivations that are affected by environmental stimuli such as floods and temperature (Agostinho et al., 2004). Bond (1979) associated these movements primarily with discharge, and secondarily with adjustments to temperature and photoperiod.

The seasonal nature of the biological processes and environmental stimuli involved in the upstream movements of fish in natural environments, suggests that the intensity of fish entry into and ascent of fish ladders will also be markedly seasonal. In this study, we sought to evaluate this seasonality and its relationships with reproduction state, temperature, river level and discharge.

\section{Materials and Methods}

The fish ladder used in this study is part of a structure developed by the Itaipu Binacional Environment and Engineering departments for the "Fish Migration Channel" experimental project (see Makrakis et al., 2007 and Hahn et al., 2007). It is located downstream from Itaipu Dam, next to the tailrace of the 15 th turbine $\left(25^{\circ} 24^{\prime} 35^{\prime \prime} \mathrm{S} ; 54^{\circ} 35^{\prime} 15^{\prime \prime} \mathrm{W}\right)$. A detailed description of this structure can be found in Fernandez et al. (2007) and Fernandez et al. (2004).

Samples of fish were taken monthly from February, 1995 through January, 1997, in two resting pools of the ladder. The first, Pool A, was the second resting pool, located $40 \mathrm{~m}$ from the base of the ladder and $10 \mathrm{~m}$ above the mean level of the Paraná River. The second, Pool B, was the fourth resting pool, located at the upper end of the ladder, $155 \mathrm{~m}$ from the base and $27 \mathrm{~m}$ above mean river level. Fish were captured in two different efforts with dip nets of two mesh sizes. To sample larger-sized fish, dip nets with a $25-\mathrm{mm}$ mesh and a mouth opening 1.0 x $0.5 \mathrm{~m}$ were operated for three minutes. The dip net used to capture smaller fish had a $15 \mathrm{~mm}$ mesh and a $0.20 \mathrm{~m}$ radius opening, operated for one minute. The analyses of these samples were carried out separately.

Data for water temperature, downstream river level, spillway discharge, and turbine discharge were obtained for each day of sampling. Temperature was measured at each sampling point, and the other data were supplied by the Itaipu Binacional Hydrology Department. Other abiotic parameters were obtained on the day of sampling and included dissolved oxygen (varied from 6.3 to $9.6 \mathrm{mg} . \mathrm{l}^{-1}$ ), electrical conductivity (46 to $59 \mu \mathrm{S} . \mathrm{cm}^{-1}$ ), and $\mathrm{pH}$ (6.6 to 7.4 ). However, because they varied only slightly during the study period, these parameters were not considered in the analyses.

\section{Data Analysis}

The patterns of temporal variability of the environmental variables and fish densities were evaluated using temporal autocorrelation, which quantifies the relationship of one variable of interest with the variable itself over a given time interval (lag), referred to as temporal $k$. The graph that relates the autocorrelation to the increase in the value of $k$ is termed a correlogram. A variable is said to show a positive temporal autocorrelation when the observations are more similar to each other, for a given $k$, than would be expected by chance. Conversely, when the observations are less similar than would be expected by chance, the variable is said to show a negative autocorrelation.

The presence of temporal autocorrelation interferes with the tests for significance by affecting the probability of type I error, that is, the criterion for rejection or acceptance of the null hypothesis. The effect of temporal autocorrelation on the significance tests can be exemplified by the Pearson's correlation coefficient. When two variables of interest have similar patterns over time (autocorrelated), the confidence interval of Pearson's coefficient, calculated by the usual procedures, is smaller than when it is calculated with the effect of autocorrelation removed. Therefore, the null hypothesis associated with the test tends to be rejected with a higher frequency than the probability of a fixed type I error (generally 0.05). This problem can also be approached by considering the calculation of degrees of freedom. In the usual statistical tests, each independent observation is equivalent to one degree of freedom. Observations that are autocorrelated are not independent, and therefore, do not provide additional degrees of freedom. As stated previously, the consequence of this is that the tests become less conservative. This means that the probability of a real type I error, in the presence of positive temporal autocorrelation, is frequently higher than stated.

In this study, autoregressive models were used to remove temporal dependence between observations. An 
autoregressive model is similar to a multiple regression analysis, except the explanatory (independent) variables consist of past values of the variable of interest. The correlation coefficients for different $k$ values were tested based on the BoxLjung statistic (Mainly, 1994).

The residuals of the autoregressive models were used to relate, using Pearson's correlation coefficient, the densities of fish to the environmental variables. The environmental variables (residuals of the autoregressive models) were previously summarized by a principal components analysis (PCA), considering that many of these variables were correlated among themselves. The PCA axes retained for interpretation were those that showed eigenvalues greater than 1 (Kaiser-Guttman Criterion). The test of correlation among the environmental variables and fish density is, in this case, valid, in view of the prior removal of temporal dependence among the observations through the use of the autoregressive models.

\section{Results}

The temporal dynamics of the environmental variables were distinct (Fig. 1a), with the correlograms for temperature showing a clear pattern of seasonality (Fig. 1b). Although the variables river level, turbine discharge and spillway discharge did not show clear seasonal dynamics, they were temporally dependent, as the autocorrelation coefficients for different values of $k$ were significant according to the Box-Ljung statistic.

In the samples of larger-sized fish in Pools A and B, 23 species were recorded during the two years of study, but six species comprised $90 \%$ of the total number of individuals collected. Most of the individuals were in a non reproductive state (non-reproducing adults, Fig. 2).

The temporal variations in abundance for most of the species showed a seasonal pattern in ascending the ladder, with low frequencies during winter (June - 6; July - 7; and August -8 ) and fluctuations during summer (Fig. 3). This pattern was more pronounced for some species in Pool B, which is located higher up the ladder. Leporinus elongatus was the most frequent large species, with a high frequency in the warmer months (October-March), especially in Pool A. This species reached Pool B in proportionally higher numbers in October and December of 1996, comprising more than $40 \%$ of the individuals that entered the ladder.

Prochilodus lineatus showed a similar pattern, with high frequencies in October, November, and February in Pool A. Leporinus friderici, in general, showed high frequencies in November through March, with higher seasonality and abundance in Pool B. However, in Pool A in the second year of study, L. friderici occurred frequently in all months of the year, even in winter. Astyanax altiparanae showed a high incidence from February through May of the first year, especially in Pool B. The opposite tendency was observed for Pimelodus maculatus and Schizodon borellii, which were more frequent in the summer of the second year; Pimelodus maculatus was more frequent in Pool B, whereas $S$. borellii was more frequent in Pool A.
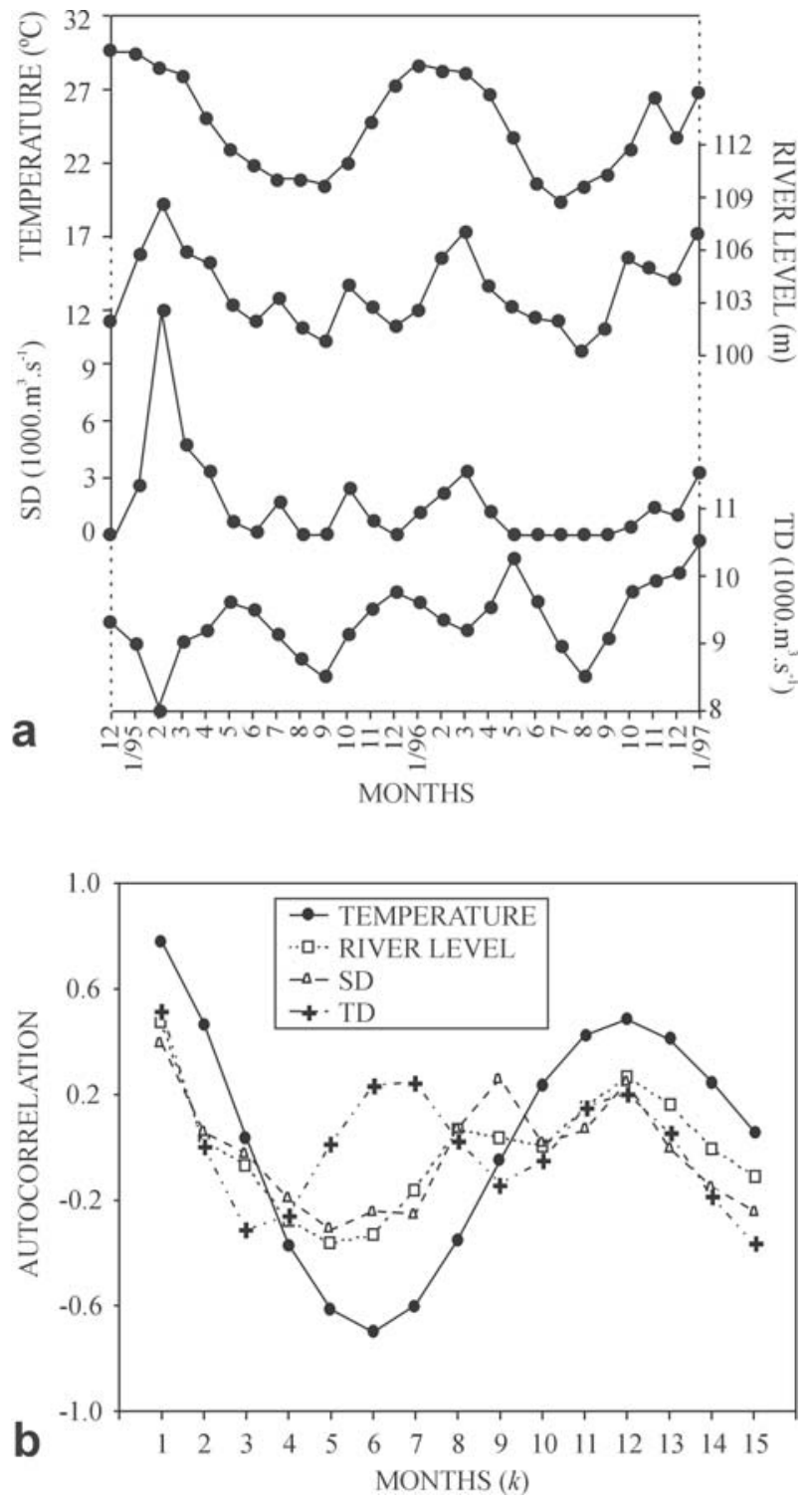

Fig. 1. Variation in temperature, river level, spillway discharge (SD) and turbine discharge (TD) at the experimental ladder located near Itaipu Dam, during the sampling period (a) and correlogram of the variables (b).

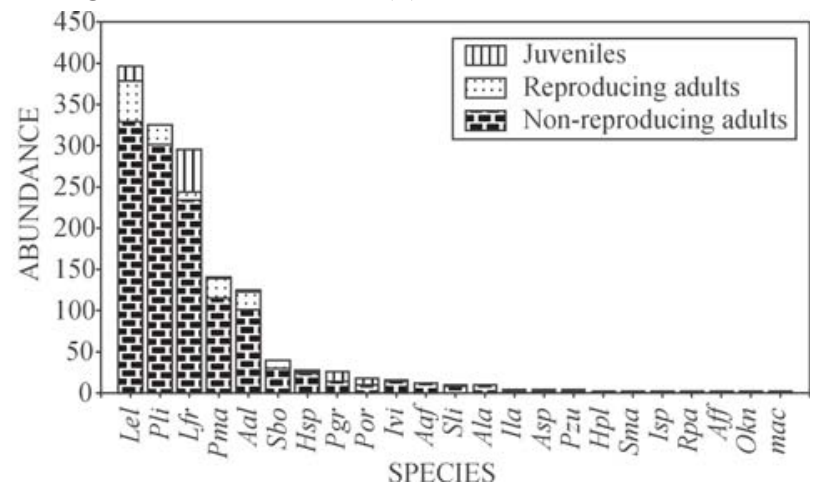

Fig. 2. Abundance of the main middle- and large-sized species of fish captured in the samples taken in the experimental fish ladder located near Itaipu Dam. The first three letters of each species (found in text) are shown. 

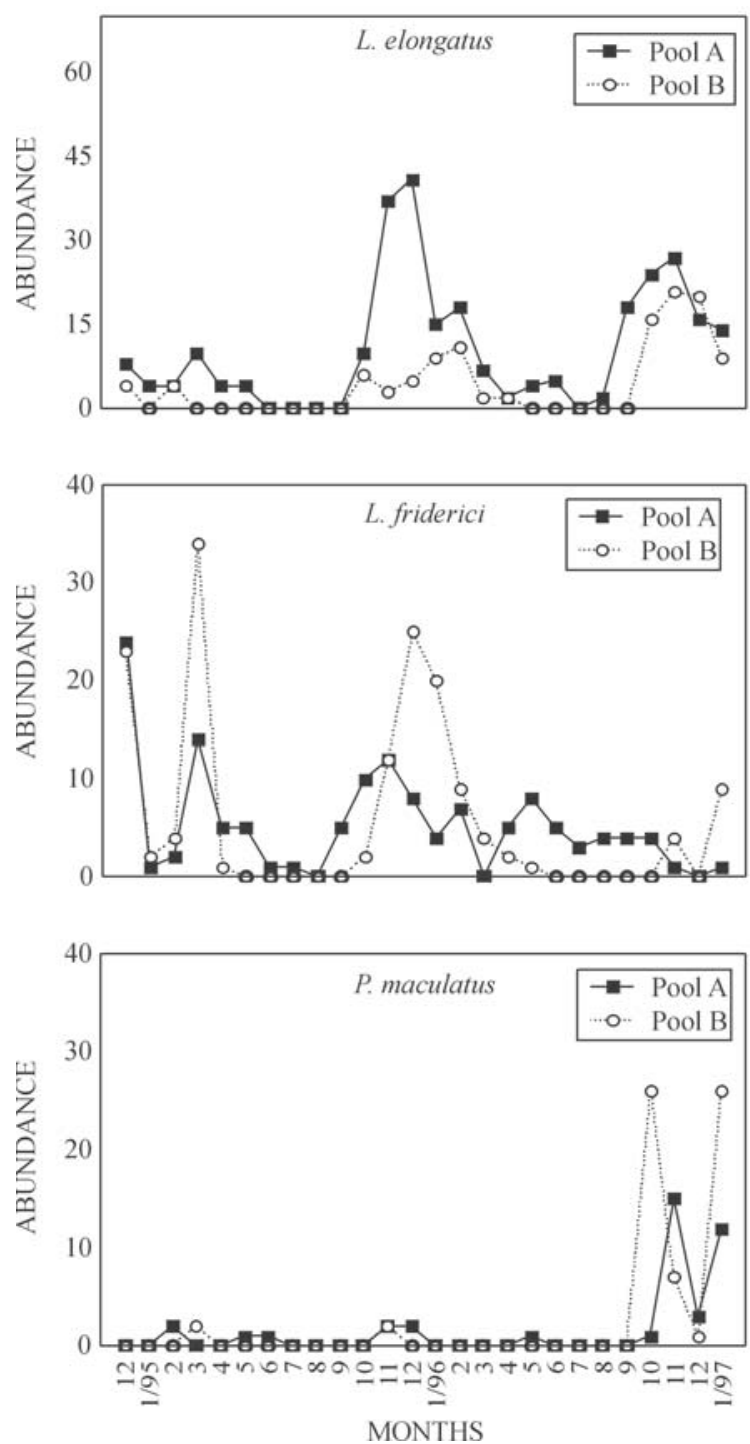
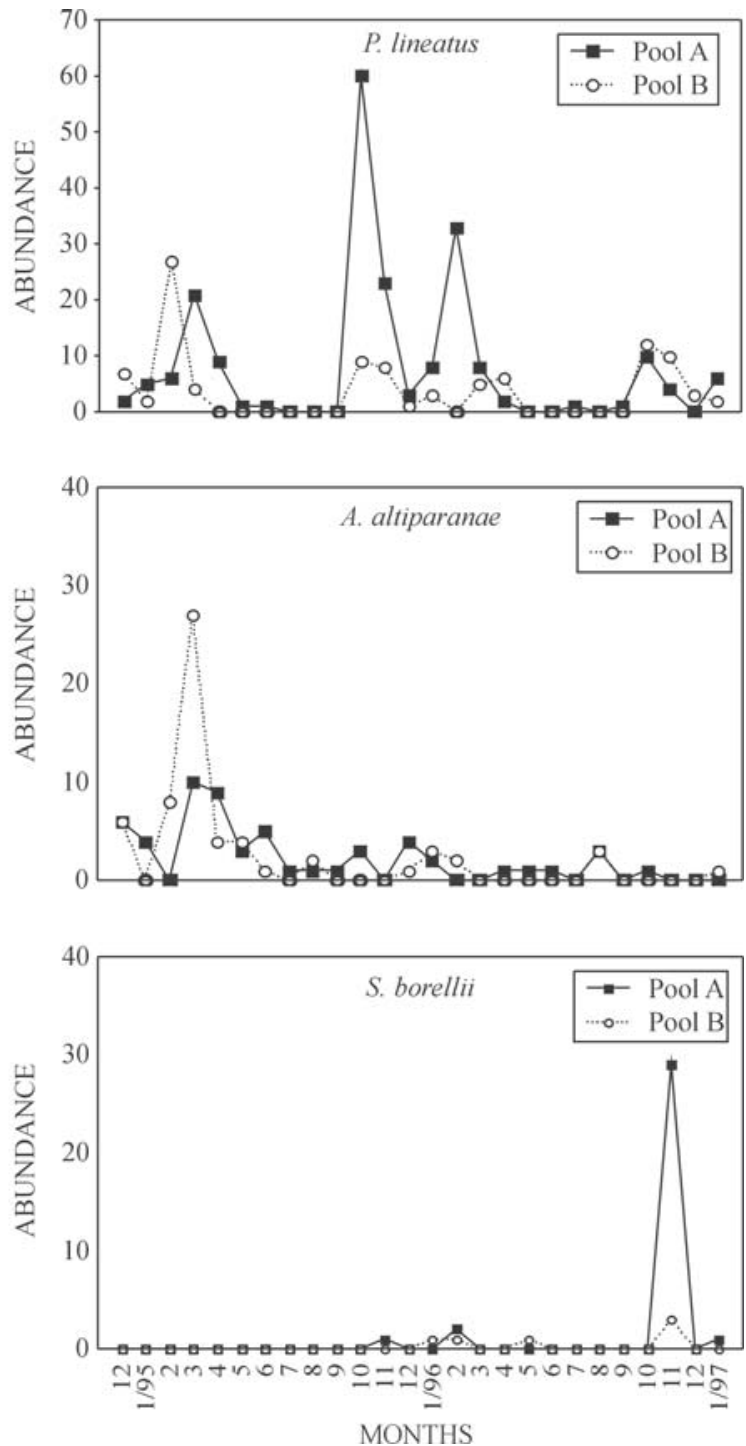

Fig. 3. Monthly variations in abundance of the main middle- and large-sized species in the experimental fish ladder (Pool $\mathrm{A}=$ $10 \mathrm{~m}$, Pool B = $27 \mathrm{~m}$ ) located near Itaipu Dam.

The temporal variability in total abundance, considering all species (Fig. 4a), indicated a seasonal pattern of variation. The highest abundance values were observed in October and February (75\%) and in Pool A (61\% of the 1343 individuals sampled). The lowest values were recorded in the winter months. The correlogram of total density confirms this tendency (Fig. 4b).

The correlograms of residuals of the autoregressive models, applied to the environmental variables and to total abundance (Fig. 5), showed that the first-order regressive models were sufficient to remove the temporal dependence among observations.

Principal components analysis of the abiotic variables indicated two components with eigenvalues greater than 1 . These explained $75.3 \%$ of the total variability of the data. Pearson's correlations between the original variables and the scores derived from the linear correlations maximizing the variability between months (principal components) indicated which were the most important variables for the formation of a particular component (Table 1). The first principal component expressed the monthly variation in river level and spillway discharge, whereas the second principal component can be interpreted as an axis that differentiated the months according to the variables temperature and turbine discharge.

The second principal component showed a significant correlation with fish abundance, for both Pool A and Pool B. Thus, fish abundances were positively related to the environmental variables, especially turbine discharge and temperature (Table 1).

In the samples taken with smaller-mesh dip nets, used to capture small-sized fish, six species were recorded, with Bryconamericus stramineus comprising $99 \%$ of the total sampled. Five other species were present, but in low percentages (Astyanax altiparanae, Astyanax fasciatus, Odontostilbe microcephala, Cheirodon sp., and Characidium sp.). Although the sampling effort was one-third of that used for the 

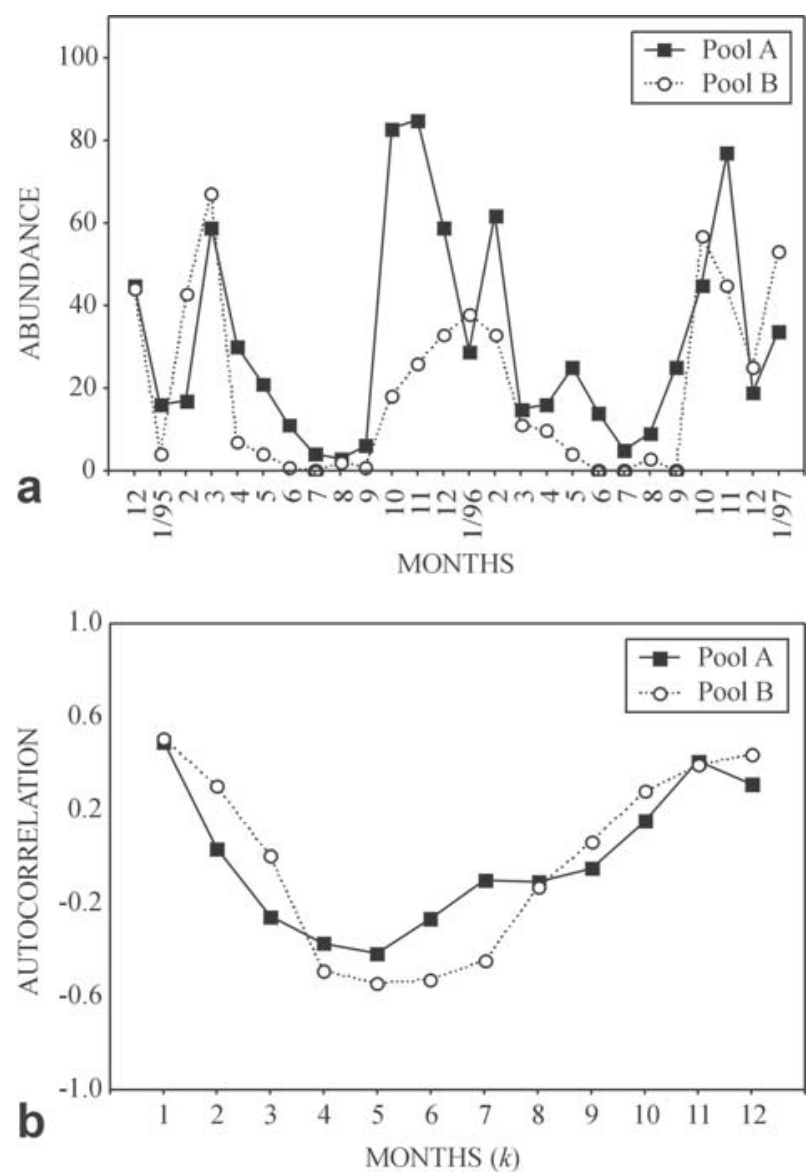

Fig. 4. Temporal variability (a) and correlogram of total abundance (b) of fish recorded in the experimental fish ladder (Pool $\mathrm{A}=10 \mathrm{~m}$, Pool B $=27 \mathrm{~m}$ ) located near Itaipu Dam.

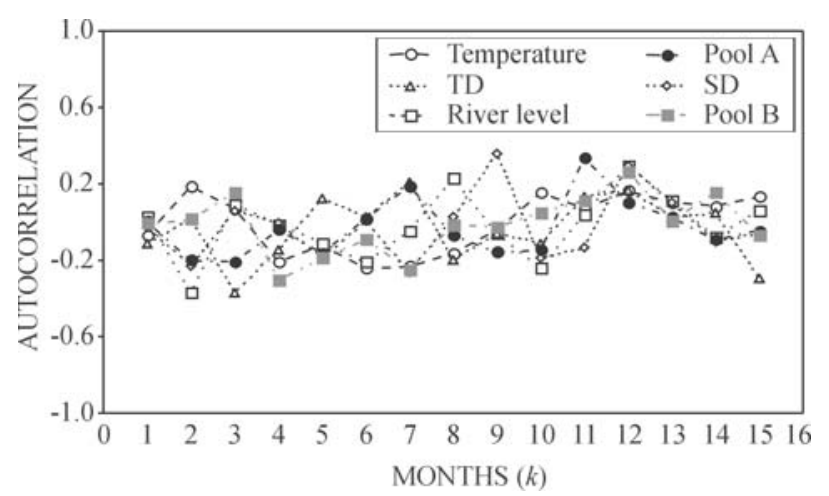

Fig. 5. Correlograms of the residuals of the autoregressive models applied (VV: spillway discharge; VT: turbine discharge) to the data collected in the experimental ladder located near Itaipu Dam.

larger fish, the frequencies of smaller fish were high, especially in the first year of study, when $90 \%$ of the total fish were recorded. On the other hand, the smaller fish were present in both pools during the entire study period, and were more frequent in Pool A (64\% of the total). The temporal variability in total abundance of small species (Fig. 6a) showed that the
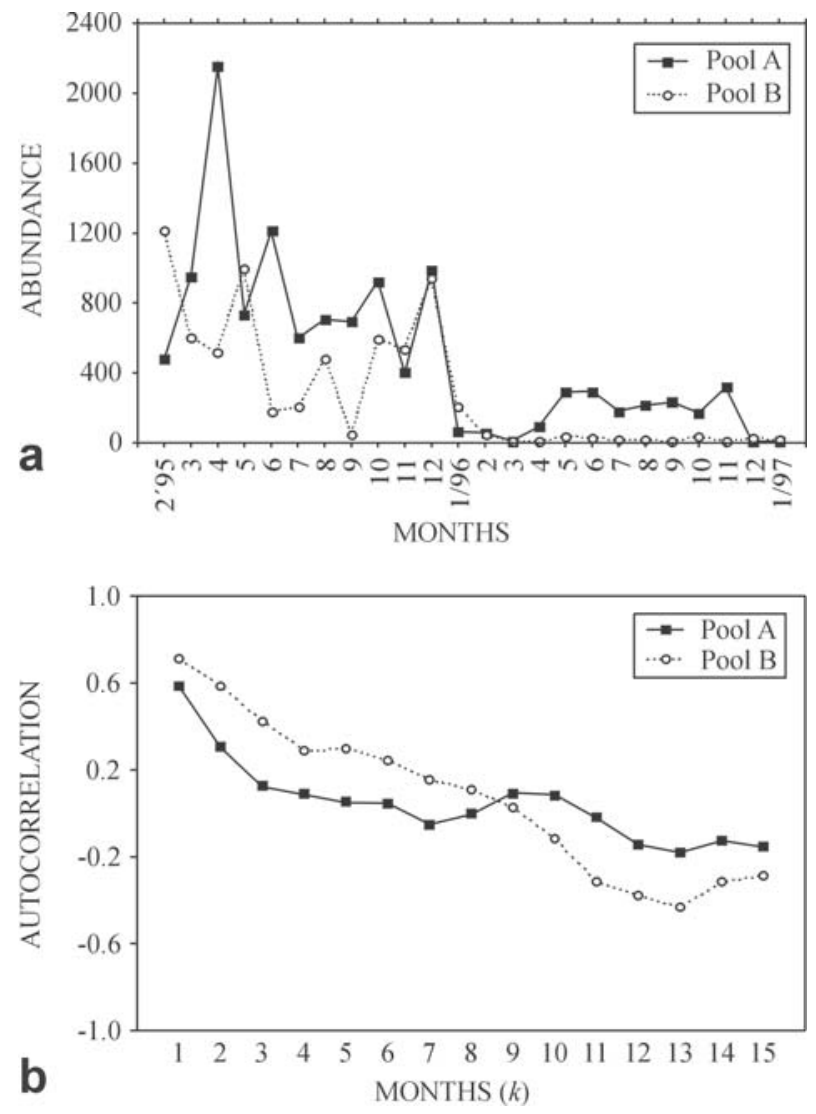

Fig. 6. Temporal variability (a) and correlogram of total abundance (b) of small-sized fish recorded in the experimental fish ladder (Pool A = 10 m, Pool B=27 m) located near Itaipu Dam.

patterns of seasonal variation differed between the two years, with the correlogram (Fig. 6b) confirming this statement.

As observed for the samples of middle- and large-sized species, the abundance of small fish did not show a significant correlation with the first component (Table 2). However, those in Pool B were correlated with the second principal component, which represents the variation on temperature and turbine discharge (see Table 1).

\section{Discussion}

The upstream movements of tropical fish, which the ladders are intended to maintain, may be of a reproductive or feeding nature. Reproductive migrations involve individuals with gonads in maturation (Godoy, 1975) that seek the uppermost stretches of the basin to spawn, often overlapping with rising river levels (Lowe-McConnell, 1987; Agostinho et al., 2004). On the other hand, feeding migrations, that usually occur in the period when the water is retreating to the main river channels (drying), are considered to be dispersal movements in search of better feeding conditions, and involve young of the year and adults (Goulding \& Carvalho, 1982; Ribeiro, 1983). Junk (1984) reported movements caused by changes in river level, and distinguished them from feeding and reproductive movements. 
Table 1. Values of the Pearson correlations between the environmental variables (residuals of the autoregressive models) and principal components 1 and 2. Pearson correlations between the fish abundance and the principal components are shown in the last two lines. The probabilities of type I error of these statistics are also shown $(P)$.

\begin{tabular}{lcccc}
\hline Variables & PC 1 & $P$ & PC 2 & $P$ \\
\hline Temperature & 0.45 & & 0.69 & \\
River level & 0.89 & & -0.07 & \\
Spillway discharge & 0.88 & & -0.06 & \\
Turbine discharge & -0.23 & & 0.83 & \\
Abundance (Pool A) & 0.17 & 0.42 & 0.57 & $\mathbf{0 . 0 0 2 7}$ \\
Abundance (Pool B) & 0.29 & 0.15 & 0.45 & $\mathbf{0 . 0 2 2 5}$ \\
\hline
\end{tabular}

In this study, the physiological motives for the fish entering and ascending the experimental ladder could not be identified. Nevertheless, the high incidence of individuals with undeveloped gonads, indicates the search for upriver spawning grounds was not the main reason for these movements. Agostinho et al. (2007c) recorded a similar high proportion of immature individuals in the fish ladder at the Lajeado Dam as well as in the downriver stretch, suggesting the possibility that this is a result of the great distance between the stretch studied and possible spawning areas upriver. In addition, the rheophilic characteristic of the species can explain their presence in the ladder (Agostinho et al., 2007b). The frequency of individuals with well-developed gonads was, however, found to be high in previous studies (Agostinho et al., 1993). The high frequency of fish with empty stomachs, especially among the non-piscivorous species (personal observations), suggests that feeding motivations may also be involved in these movements. Nevertheless, the ascent in the ladder was markedly seasonal, with greater intensities in the warmer months (October through February), when reproductive activity is greater (Vazzoler, 1996; Agostinho et al., 2004) and discharge is generally higher. A similar seasonality was reported by Agostinho et al. (2007a).

In addition to the endogenous motivation, environmental stimuli such as temperature, water velocity, discharge and river level appear to play an important role in the upstream migration of fish (Godoy, 1985; Vazzoler, 1996). In this study, under conditions of constant velocity and discharge in the ladder, water temperature and turbine discharge significantly influenced the intensity of ascent. Spillway discharge and river level had little influence on ascent, which is partly explained by the location of the spillway basin, about $1000 \mathrm{~m}$ downstream from the base of the ladder. Agostinho et al. (2007b) reported that the seasonal variation in downriver water levels influences both species richness and abundance in the fish ladder at Lajeado Dam and in the stretch of river downstream from the ladder, with lower values during the low-water period.

The role of temperature in the swimming activity of fish has been fully recognized in the literature (Baker \& Vatapka, 1990; Prignon et al., 1998). During this study, carried out at mean daily temperatures ranging from 19.7 to $30^{\circ} \mathrm{C}$, more than $70 \%$ of the catches at Pool A and $91 \%$ of those at Pool B were
Table 2. Values of the Pearson correlations between the abundance of small-sized fish at each point along the ladder (Pools A and B) located near Itaipu Dam and the principal components that summarized the variables considered. ( $P=$ probability of type I error).

\begin{tabular}{ccccc}
\hline Variables & PC 1 & $P$ & PC 2 & $P$ \\
\hline Abundance (Pool A) & 0.266 & 0.220 & 0.401 & $\mathbf{0 . 0 5 8}$ \\
Abundance (Pool B) & 0.027 & 0.902 & 0.436 & $\mathbf{0 . 0 3 8}$ \\
\hline
\end{tabular}

at temperatures above $24^{\circ} \mathrm{C}$. This provides evidence that not only the frequency of entry into the ladder, but also the efficiency with which the fish reached the higher stretches increased. In this respect, Haro et al. (1999) reported observations on species of Alosa in Alaska, in which an increase in temperature led to an increase in fish ascent and a decrease in the time required for fish to pass through fish-passage facilities. Kynard (1998), evaluating the movements of sturgeon in Holzoku Reservoir (Connecticut River, USA), established that, with the temperature varying between 10 and $27^{\circ} \mathrm{C}, 86 \%$ of the catch occurred between 12 and $23^{\circ} \mathrm{C}$. Jensen et al. (1998), studying the movements of fish in streams, found that under low-temperature conditions, even small obstacles could be insurmountable. Northcote (1998) associated the migration rates of fish with the effect of temperature on their endocrine cycles, which is strong in fish because they are poecilotherms.

In the present study, the water discharge and velocity in the ladder were kept constant, at $3231 . \mathrm{s}^{-1}$ and $2.2 \mathrm{~m} \cdot \mathrm{s}^{-1}$, respectively. Discharge is more related to the attraction of the fish to enter the ladder, whereas water velocity is more related to their success in ascending it. The attraction discharge is one of the most important aspects of any fish pass structure (Clay, 1995; Larinier, 2002b), whereas the velocity can affect movement through the fish pass. Observations of Quirós (1988) indicated that velocities above $3.6 \mathrm{~m} \cdot \mathrm{s}^{-1}$ impede ascent of fish in ladders. The optimum and limiting water velocities must vary according to species. Thus, velocities above 1.5 $\mathrm{m} . \mathrm{s}^{-1}$ were limiting to the ascent of Alosa spp. for a fish passage in the Rhône River below Lyon, France (Larinier et al., 1978). For juveniles of Macquaria novemaculeata and Lates calcarifer, this value was slightly lower $1.4 \mathrm{~m} \cdot \mathrm{s}^{-1}$ ( MallenCooper, 1992). Ebel (1985), in a study of salmonids, indicated that the critical water velocity was about $4.0 \mathrm{~m} . \mathrm{s}^{-1}$. The values obtained in this study and those reported by Quirós (1988) show that the swimming abilities of fishes of the Paraná River basin are close to those of salmonids.

The attraction discharge must also be considered in terms of discharge competition. It is strongly influenced by the location of the entrance to the fish pass, which competes with discharge from the turbines and spillway basin in attracting fish during their migration (Parasiewicz et al. 1998; Larinier, 2002b). The proximity of the ladder to the turbines, in contrast to the spillway, explains the positive relationship between the number of fish entering the ladder and the turbine discharge found in this study. This discharge varied between 8,172 and $10,559 \mathrm{~m}^{3} \cdot \mathrm{s}^{-1}$, and more than $60 \%$ of the catch in the ladder occurred when it exceeded $9,400 \mathrm{~m}^{3} \cdot \mathrm{s}^{-1}$. It 
is likely that an increase in the discharge attracts fish to the vicinity of the ladder.

The occurrence of high turbine discharges in conditions of low water temperatures (May and June) did not result in increased entry of fish into the ladder, which suggests seasonality in the occurrence of migratory fishes in the vicinity, or reduced swimming activity. The number of sexually mature brown trout Salmo trutta ascending the fish ladder at Hunder Reservoir on the Gudbbrandsdalslaagen River, in Eastern Norway, during 1983-90, was correlated with river discharge and with water temperature (Jensen \& Aass, 1995). Besides discharge and temperature, other environmental factors have been been related to fish migration. Prominent among these factors are photoperiod (Bond, 1979), dissolved oxygen (Bates, 1997), and the size and body shape of individuals (Zhao \& Han, 1980; Peake et al., 1995; Lucas \& Baras, 2001).

The hydraulics associated with the experimental fish ladder located near the Itaipu Dam appeared promising for the attraction and ascent of some species of fishes. Therefore, it may be used at other dams on the Paraná River, but it is appropriate to emphasize that studies of the factors that affect the movements of fish and analysis of the efficiency of these facilities represent only one of the stages that must be accomplished before constructing any fish passage. Information on the time required and success rate of individually tagged fish to pass the ladder, using electronic (PIT, radio, or acoustic), or other tag types that uniquely identify individual fish would provide valuable information. It is also necessary to confirm the existence of favorable areas for reproduction and development (nurseries) in the upriver stretches, to analyze the viability of individual fish once they have passed the dam and actually reached these areas, and finally, to verify that a benefit from recruitment extends to the stretch downriver from the dam.

\section{Literature Cited}

Agostinho, A. A. \& L. C. Gomes. 2005. O manejo da pesca em reservatórios da bacia do alto rio Paraná: avaliação e perspectivas. In: Nogueira, C. \& R. Henry. Ecologia de reservatórios: Impactos potenciais, ações de manejo e sistemas em cascata. Pp. 23-55. São Carlos, Editora Rima, 459p.

Agostinho, A. A., L. C. Gomes, D. R. Fernandez \& H. I. Suzuki. 2002. Efficiency of fish ladders for neotropical ichthyofauna. River Research and Application, 18(3):299-306.

Agostinho, A. A., L. C. Gomes \& F. M. Pelicice. 2007a.Ecologia e manejo de recursos pesqueiros em reservatórios do Brasil. Maringá, EDUEM, 512 p.

Agostinho, A.A., L. C. Gomes, S. Veríssimo \& E. K. Okada. 2004. Flood regime, dam regulation and fish in the Upper Paraná River: effects on assemblage attributes, reproduction and recruitment. Reviews in Fish Biology and Fisheries, 14: 11-19.

Agostinho, A. A., V. P. Mendes, H. I. Suzuki \& C. Canzi. 1993. Avaliação da atividade reprodutiva da comunidade de peixes dos primeiros quilômetros a jusante do Reservatório de Itaipu. Revista UNIMAR, 15:175-189.

Agostinho, C. S., A. A. Agostinho, F. M. Pelicice, D. A. A. Almeida
\& E. E. Marques. 2007b. Selectivity of fish ladders: a bottleneck in Neotropical fish movement. Neotropical Ichthyology, 5(2): 205-213.

Agostinho, C. S., C. R. Pereira, R. J. Oliveira, I. S. Freitas \& E. E. Marques. 2007c. Movements through a fish ladder: temporal patterns and motivations to move upstream. Neotropical Ichthyology, 5(2): 161-167.

Baker, C. O. \& F. E. Votapka. 1990. Fish Passage Though Culverts. U.S. Department of Agriculture, Forest Service, and U.S. Department of Transportation, Federal Highway Administration Report No. FHWA-FL-90-006.

Bates, K. 1992. Fishway design guidlines for Pacific salmon. Working paper 1.6, Washington Department of Fish and Wildlife, Olympia WA. 110p.

Bond, C. E. 1979. Biology of Fishes. Philadelphia, Saunders College Publishing. 514p.

Britski, H. 1994. As bacias hidrográficas e a preservação da biodiversidade. In: Comase/Eletrobras. Seminário sobre fauna aquática e o Setor Elétrico Brasileiro. Caderno 6, 30-37.

Clay, C. H. 1995. Design of Fishways and Other Fish Facilities. Second Edition. Boca Raton, Lewis Publishers, 244p.

Ebel, W. J. 1985. Review of effects of environmental degradation on the freshwater stages of anadromous fish. Pp. 62-79. In: Alabaster, J. (Ed) Habitat Modification and Freshwater Fisheries. Food and Agriculture Organization of the United Nations. 320p.

Fernandez, D. R., A. A. Agostinho \& L. M. Bini. 2004. Selection of an experimental fish ladder located at the dam of the Itaipu Binacional, Brazil. Brazilian Archives of Biology and Technology, 47(4):579-586.

Fernandez, D. R., A. A. Agostinho, L. M. Bini \& F. M. Pelicice. 2007. Diel variation in the ascent of fishes up an experimental fish ladder at Itaipu Reservoir: fish size, reproductive stage and taxonomic group influences. Neotropical Ichthyology, 5(2): 215-222.

Godoy, M. P. 1975. Peixes do Brasil, Subordem Characoidei, Bacia do rio Mogi Guaçu, Piracicaba, Brasil. Editora Franciscana. 4 volumes. $846 \mathrm{p}$.

Godoy, M. P. 1985. Aquicultura. Atividade multidisciplinar. Escadas e outras facilidades para passagens de peixes. Estações de piscicultura. Florianópolis, Brazil, Eletrosul, 77p.

Goulding, M. \& M. L. Carvalho. 1982. Life History and management of the tambaqui (Colossoma macropomum; Characidae): an important Amazonian food fish. Revista Brasileira de Zoologia, 1(2):107:33.

Hahn, L., K. English, J. Carosfeld, L. C. G. M. da Silva, J. D. Latini, A. A. Agostinho \& D. R. Fernandez. 2007. Preliminary study on the application of radiotelemetry techniques to evaluate movements of fish in the Lateral Canal at the Itaipu Dam, Brazil. Neotropical Ichthyology, 5(2): 103-108.

Haro, A., M. Odeh, T. Castro-Santos \& J. Noreika. 1999. Effect of slope and headpond on passage of American shad and blueback herring through simple Denil and deepened Alaska steeppass fishways. North American Journal of Fisheries Management, 19(1):51-58.

Jensen, A. J. \& P. Aass. 1995. Migration of a fast-growing population of brown trout (Salmo truta) through a fish ladder in relation to water flow and water temperature. Regulated Rivers: Research \& Management, 10(3-4):217-228.

Jensen, A. J., N. A. Hvidsten \& B. Johnsen. 1998. Effects of temperature and flow in two Norwegian rivers. Pp. 45-54. In: Junwirth, M., S. Schmutz \& S. Weiss (Eds). Fish Migration and Fish Bypasses. London, Fishing News Books, 434p. 
Junk, W. J. 1984. Ecology, fisheries and fish culture in Amazon. Pp. 443-476. In: Sioli, H. The Amazon: Limnology and Landscape Ecology of a Mighty Tropical River and its Basin. Dordrecht, Dr W. Junk.

Kynard, B. 1998. Twenty-two years of passing shortnose sturgeon in fish lifts on the Connecticut River: What has been learned? Pp. 255-264. In: Junwirth, M., S. Schmutz \& S. Weiss (Eds). Fish Migration and Fish Bypasses. London, Fishing News Books, 434p.

Larinier, M. 2002a. Fishways: general considerations. In M. Larinier, F. Travade \& J. P. Porcher (Eds) Fishways: biological basis, design criteria and monitoring. Bulletin Français de la Pêche et de la Pisciculture, 364:21-27.

Larinier, M. 2002b. Location of fishways. In: M. Larinier, F. Travade \& J. P. Porcher (Eds). Fishways: biological basis, design criteria and monitoring. Bulletin Français de la Pêche et de la Pisciculture, 364:39-53.

Larinier, M., B. Rivier, J. Allardi \& F. Trocherie. 1978. Dam passing possibilities for Rhone shads at Beaucaire. Bulletin Français de la Pêche et de la Pisciculture, 268:107-120.

Lowe-McConnell, R. H. 1987. Ecological studies in tropical fish communities. Cambridge, Cambridge University Press, 382p.

Lucas, M. C. \& E. Baras. 2001. Migration of freshwater fishes. London, Blackwell Science Ltd., 420p.

Makrakis, S., L. C. Gomes, M. C. Makrakis, D. R. Fernandez \& C. S. Pavanelli. 2007. The Canal da Piracema at Itaipu Dam as a fish pass system. Neotropical Ichthyology, 5(2): 185-195.

Mallen-Cooper, M. 1992. Swimming ability of juvenile Australian bass, Macquaria novemaculeata, and juvenile barramundi, Lates calcarifer in an experimental vertical slot fishway. Australian Journal of Marine and Freshwater Research, 43(4):823-834.

Manly, B. F. J. 1994. The design and analysis of research studies. Cambridge, Cambridge University Press, 353p.
Northcote, T. G. 1998. Migratory behavior of fish and its significance to movement through riverine fish passage facilities. Pp. 3-18. In: Junwirth, M., S. Schmutz \& S. Weiss (Eds). Fish Migration and Fish Bypasses. London, Fishing News Books, 434p.

Parasiewicz, P., J. Eberstaller, S. Weiss \& S. Schmutz. 1998. Conceptual guidelines for nature-like bypass channels. Pp. 348362. In: Junwirth, M., S. Schmutz \& S. Weiss (Eds). Fish Migration and Fish Bypasses. London, Fishing News Books, $434 \mathrm{p}$.

Peake, S., F. W. H. Beamish, R. S. Mckinley, C. Katopodis \& A. Scruton. 1995. Swimming performance of lake sturgeon, Acipenser fulvescens. Canadian Technical Report in Fishery and Aquatic Sciences, 2063. 30p.

Prignon, C., J. C. Micha \& A. Gillet. 1998. Biological and environmental characteristics of fish passage at the Tailfer Dam on the Meuse River, Belgium. Pp 69-84. In: Junwirth, M., S. Schmutz \& S. Weiss (Eds). Fish Migration and Fish Bypasses. London, Fishing News Books, 434p.

Quirós, R. 1988. Structures Assisting Migrations of Fish Other than Salmonids: Latin America, FAO-COPESCAL Tech. Doc. $\mathrm{n}^{\circ} 5$, Food and Agriculture Organization of the United Nations, Rome. 50p.

Ribeiro, M. C. L. 1983. As migrações dos jaraquis (Pices, Prochilodontidae) no rio Negro, Amazonas, Brasil. Unpublished MSc Dissertation. Instituto Nacional de Pesquisas da Amazonia, Manaus. 160p.

Vazzoler, A. E. A. de M. 1996. Biologia da Reprodução de Peixes Teleósteos: Teoria e Prática. Editora da Universidade Estadual de Maringá (EDUEM), Maringá, Brazil, 169p.

Zhao, X. \& Z. Han. 1980. Experiments on the current overcoming ability of some freshwater fishes. Journal of Fisheries, 4(1):3137.

Received January 2007 Accepted June 2007 